\title{
UMA HAVANA SENSUAL E PERIGOSA
}

\author{
Jefson Jesus de Souza ${ }^{\mathrm{I}}$
}

GUTIERREZ, Pedro Juan. Trilogia suja de HAVANA. I ed. Lisboa, 1998.

Abominamos a falsidade. Desconjuramos a verdade a qualquer custo, mesmo que ela seja uma navalha suja e contaminada. Bem, abram caminho, pois o macho tropical tem algo a sussurrar. Sim, faça de conta que o escritor está sussurrando em seu ouvido palavras "calientes" de um livro, com uma voz sedutora e, ao mesmo tempo, voraz. E agora sobrevoaremos um romance lotado de sinceridade e sem artificialismos, sem falsidade. Trilogia Suja de Havana, a obra do escritor cubano Pedro Juan Gutiérrez, impressiona, apesar do relato cru de uma Havana miserável dos anos 90, onde tudo parece estar em ruínas, efervescência, e colabora para uma ruptura moral que choca e atropela.

O escritor utilizando-se de um intenso erotismo que transborda o copo do pudor faz da realidade de Havana um conteúdo de episódios da fome e da escassez explorando a vida social, econômica e política do seu povo. E isso é o que mais doa ritmo a narração. Se afogando num mundo de sexo e vícios no auge da crise cubana o autor ignora a hipocrisia e relata a Cuba de Fidel servindo-se de todo perímetro da realidade, sem pôr e nem tirar. Eu o comparo com Herry Miller, e mais adiante, com Charles Bukowski, escritores carnais que captam a realidade tanto pelo olhar quanto pela audição, tanto pelo tato quanto pelo paladar, e extraem dessa algo sólido, palpável. Ele compõe uma cidade feita de desejos e medos, e reflete, como num espelho, a luta por sobrevivência do povo cubano em meio ao desastre e a miséria. Relata um tempo em que não há comida e nem trabalho numa Havana sensual e perigosa cujo povo vive no "salve-se quem puder" e soterrados por sexo, drogas e rum.

\footnotetext{
Graduando em medicina pela Universidade Federal do Sul da Bahia- UFSB. Email:negromontejeff@yahoo.com.br
} 
O que Pedro Juan tem a oferecer em Trilogia Suja de Havana é o retrato caótico de uma Cuba autoritária que parece não ter vontade de se reformular. Existe o conflito no livro e esse conflito aborda desencanto. E, vejam, há toda uma verdade no romance. Toda uma realidade sendo narrada com sinceridade. Tudo que um ótimo romance tem que ter.

Compreender o romance de Pedro Juan como uma síntese do universo comunista é fundamental e faz gerar, principalmente, reflexões sobre o quanto de verdade há em seu conteúdo, afinal, para quem nunca esteve em Cuba, deve plantar dúvidas sobre a real miséria vivida pela sua população. Miséria está que o escritor descreve com mínimos detalhes em sua trama que, parece ser, autobiográfica. Não há a intenção, claro, de denegrir o livro, porém, é súbita a proposta da dúvida nesse contexto que conduz o enredo por um lado politico que é colocado com pitadas muito bem direcionadas. $\mathrm{O}$ romance, entrega, mais que um relato, um desabafo, sobre a situação de Cuba no tempo que era governado por Fidel Castro, onde para se conseguir uma ou outra coisa era uma dificuldade e a falta de perspectiva endossava a vida das pessoas na periferia. Pedro Juan fez uma obra de peso com uma visão que empolga e que prende o leitor de maneira que construímos uma Cuba que vai além das últimas páginas do livro. 